DOI: 10.1590/1809-6891v19e-51322

CIÊNCIAS BIOLÓGICAS

\title{
EVALUATION OF THE ANTIBACTERIAL ACTIVITY OF Crotalus durissus terrificus CRUDE VENOM
}

\section{AVALIAÇÃO DA ATIVIDADE ANTIBACTERIANA DO VENENO BRUTO DE Crotalus durissus terrificus}

\author{
Jefferson do Carmo Dietz ${ }^{1}$ \\ Daniela Andrade de Almeida ${ }^{1}$ \\ Lorena Cardoso Cintra ${ }^{1}$ \\ Bruno Francesco Rodrigues de Oliveira ${ }^{1 *}$ \\ Marta Regina Magalhães ${ }^{2}$ \\ Rosália Santos Amorim Jesuíno ${ }^{1}$ \\ ${ }^{1}$ Universidade Federal de Goiás, Goiânia, GO, Brazil. \\ ${ }^{2}$ Pontifícia Universidade Católica de Goiás \\ *Corresponding author - bfro.francesco@gmail.com
}

\begin{abstract}
Snake venoms are recognized as a promising source of pharmacologically active substances and are potentially useful for the development of new antimicrobial drugs. This study aimed to investigate the antimicrobial activity of the venom from the rattlesnake Crotalus durissus terrificus against several bacteria. Antibacterial activity was determined by using the plate microdilution method and the activity on the bacterial envelope structure was screened by using the crystal violet assay. The proteins in crude venom were separated by electrophoresis and characterized regarding their proteolytic activity. $C$. d. terrificus venom exhibited antimicrobial action against gram-positive and gram-negative bacteria. MIC values were defined for Pseudomonas aeruginosa ATCC 27853 (62.5 $\mu \mathrm{g} / \mathrm{mL})$, Staphylococcus aureus ATCC 25923 (125 $\mu \mathrm{g} / \mathrm{mL})$, and Micrococcus luteus ATCC 9341 $(\leq 500 \mu \mathrm{g} / \mathrm{mL})$. For Salmonella enterica serovar typhimurium ATCC 14028 and Corynebacterium glutamicum ATCC 13032, the decrease in bacterial growth was not detected visually, but was statistically significant. The crystal violet assay demonstrated that the crude venom increased bacterial cell permeability and the secreted protein profile agreed with previous reports. The results suggest that the proteins with lytic activity against bacteria in $C$. $d$. terrificus venom deserve further characterization as they may offer reinforcements to the weak therapeutic arsenal used to fight microbial multidrug resistance.
\end{abstract}

Keywords: rattlesnake venom, antimicrobial action, cellular envelope, proteolytic activity.

\section{Resumo}

Os venenos de serpentes são reconhecidos como uma fonte promissora de substâncias farmacologicamente ativas e potencialmente úteis para o desenvolvimento de novas drogas antimicrobianas. Esse trabalho teve como objetivo investigar a atividade antimicrobiana do veneno de Crotalus durissus terrificus contra várias bactérias. A determinação da atividade antibacteriana foi 
realizada pelo método de microdiluição em placas e a ação na estrutura do envelope bacteriano pelo ensaio violeta de cristal. As proteínas do extrato bruto foram separadas por eletroforese e caracterizadas quanto à sua atividade proteolítica. $\mathrm{O}$ veneno de $C$. $d$. terrificus apresentou ação antimicrobiana frente bactérias gram-positivas e gram-negativas. Os valores de MIC foram definidos para Pseudomonas aeruginosa ATCC $27853(62.5 \mu \mathrm{g} / \mathrm{mL})$, Staphylococcus aureus ATCC 25923 $(125 \mu \mathrm{g} / \mathrm{mL})$ e Micrococcus luteus ATCC $9341(\leq 500 \mu \mathrm{g} / \mathrm{mL})$. Para Salmonella enterica serovar typhimurium ATCC 14028 e Corynebacterium glutamicum ATCC 13032, o decréscimo no crescimento bacteriano não foi detectado visualmente, mas foi estatisticamente significante. $\mathrm{O}$ teste do cristal violeta demonstrou que o veneno bruto aumentou a permeabilidade das células bacterianas e o perfil de proteína secretada está em consonância com relatos anteriores. Os resultados sugerem que as proteínas com atividade lítica contra bactérias no veneno de $C$. $d$. terrificus merecem atenção para uma melhor caracterização, uma vez que podem trazer reforços para o escasso arsenal terapêutico empregado para combater a multirresistência microbiana.

Palavras-chave: veneno de cascavel, ação antimicrobiana, envelope celular, atividade proteolítica.

Received on: February, 01, 2018.

Accepted on: August, 23, 2018.

\section{Introduction}

Snakes of the genus Crotalus are commonly known as rattlesnakes. They are characterized by the presence of a terminal rattle in the tail that produces a particular noise when threatened or excited. Rattlesnakes are found in dry, sandy, and stony areas, such as open and closed fields, but are absent from coastal or dense vegetation. They measure approximately one meter in length, with yellowishbrown coloration and a robust body ${ }^{(1)}$. In Brazil, the genus is represented only by one species, Crotalus durissus, which has seven subspecies: $C$. d. dryinas, $C . d$. marajoensis, $C . d$. ruruima, $C . d$. trigonicus, $C$. d. terrificus, $C$. d. cascavella, and C. d. collilineatus ${ }^{(2)}$. Crotalus. d. terrificus probably originated from a stock of the nominal race (Crotalus durissus) in Mexico and occupied the open areas of South America. They occur in the southern Amazon rainforest, extreme southeastern Peru, Bolivia, Paraguay, Uruguay, and northern Argentina and are likely to be found in urban areas as a consequence of deforestation. The various known subspecies are parapatric forms that have been diversified by speciation ${ }^{(3,4)}$.

Snake venom is an important evolutionary adaptation essentially used for predation. They are primarily composed of a complex mixture of proteins and peptides, usually toxins, which act synergistically and exert a wide range of pharmacological activities, such as neurotoxic, hemotoxic, and cytotoxic effects on prey and humans ${ }^{(5)}$. The most common components found in rattlesnake venoms are enzymes, primarily nucleases, hyaluronidases, L-amino acid oxidases (LAAOs), different metalloproteinases, serine proteases, and phospholipases ${ }^{(6,7)}$. In $C$. durissus species, the fractionation of the venom has evidenced the presence of polypeptidic toxins, mainly crotoxin and crotamine, with smaller proportions of gyroxin and convulxin ${ }^{(8,9)}$. Together, the inoculation of these constituents in an ophidian accident can promote several physiological disorders with effects on the nervous, cardiovascular, and neuromuscular systems, and on coagulation and hemostasis ${ }^{(10)}$. 
Many components of snake venoms led to drugs that act on the cardiovascular system, such as the antihypertensive Captopril $\AA^{\circledR}$, and blood hemostasis, for example, the anti-thrombotic Integrilin $\AA$, as well as drugs with anti-inflammatory, analgesic, immunomodulatory, antineoplastic, and even antibiotic action $^{(11-13)}$. The venoms of various snake species also exhibit antimicrobial activity against gram-positive, gram-negative bacteria, retroviruses, and protozoa, such as Leishmania and Trypanosoma cruzi, especially the enzymatic components such as PLAs 2 and metalloproteinases. The enzymes act commonly through the hydrolysis of membrane phospholipids; in addition to L-amino acid oxidases and flavoproteins, whose biological activity results from the induction of oxidative stress $^{(14-18)}$.

Owing to the need for new therapeutic alternatives for the treatment of microbial infections, the investigation of Crotalus venom for potential antimicrobial agents is an obvious choice. Therefore, the aim of the present study was to evaluate the antimicrobial activity of $C$. $d$. terrificus crude venom, concomitantly screen for a possible mechanism of action on the bacterial cellular envelope, and analyze its protein profile and enzymatic activity.

\section{Material and Methods}

The venom of $C$. $d$. terrificus was extracted from one adult male specimen by manual massage of the venom gland, and clarified by centrifugation at $24,000 \times \mathrm{g}$ for $12 \mathrm{~min}$ at $4{ }^{\circ} \mathrm{C}$. The supernatant was then lyophilized as described previously by Ribeiro et al. ${ }^{(19)}$. After that, $1.0 \mathrm{mg}$ of venom was diluted in $1.0 \mathrm{~mL}$ volume of sterile Milli-Q water $(1.0 \mathrm{mg} / \mathrm{mL})$ and stored at $-20{ }^{\circ} \mathrm{C}$. The specimen of $C$. $d$. terrificus was kept in captivity at the Center of Biological Studies and Research (CEPB) of the Pontifical Catholic University of Goiás (PUC-GO), Goiânia, Brazil. The experimental protocol was approved by the Ethics Committee on Animal Use at the PUC-GO (Protocol 0008/1).

Gram-positive and gram-negative bacterial strains were used as indicators in the screening tests of antibacterial activity: Staphylococcus aureus ATCC 25923, Micrococcus luteus ATCC 9341, Corynebacterium glutamicum ATCC 13032, Bacillus subtilis ATCC 6633, Escherichia coli ATCC 25922, Klebsiella pneumoniae ATCC 70063, Serratia marcescens ATCC 14756, Salmonella enterica serovar Typhimurium ATCC 14028, and Pseudomonas aeruginosa ATCC 27853. The strains were stored in a freezer at $-20^{\circ} \mathrm{C}$. For the experiments, the strains were first grown in brain heart infusion (BHI) broth for $24 \mathrm{~h}$ at $37^{\circ} \mathrm{C}$ and subsequently on nutrient agar for $24 \mathrm{~h}$ at $37^{\circ} \mathrm{C}$.

A microdilution test, performed in accordance with the Clinical and Laboratory Standards Institute (CLSI) $^{(20)}$, was used to evaluate bacterial susceptibility to different concentrations of the $C$. $d$. terrificus venom. Initially, isolated colonies from bacterial cultures were suspended in $3 \mathrm{~mL}$ sterile saline solution $(0.85 \%, \mathrm{w} / \mathrm{v})$ and the turbidity was adjusted to MacFarland standard 0.5 . Subsequently, the material was diluted 1:10 (v/v) in saline solution to $10^{7}$ colony forming units $/ \mathrm{mL}$. Double-strength Mueller-Hinton broth was prepared and $100 \mu \mathrm{L}$ was transferred to each well of a 96-well microplate. First, $100 \mu \mathrm{L}$ of a $1.000 \mu \mathrm{g} / \mathrm{mL}$ solution of $C$. d. terrificus venom was added to the first column. Thereafter, serial dilutions were performed to produce crude venom concentrations between 500 and $0.49 \mu \mathrm{g} / \mathrm{mL}$. Finally, $10 \mu \mathrm{L}$ of bacterial inoculum was added to each well, and the plates were incubated for $18 \mathrm{~h}$ at $35^{\circ} \mathrm{C}$. Each test was performed in triplicate. Three distinct controls were used in the experiment: (1) control of microbial growth, in which Mueller-Hinton broth and bacterial 
inoculum were added to the wells; (2) control of medium sterility, in which Mueller-Hinton broth was added to the wells; (3) in which Mueller-Hinton liquid medium and $1.000 \mu \mathrm{g} / \mathrm{mL}$ venom solution were added to the well.

After the incubation period, $20 \mu \mathrm{L}$ of $0.5 \%(\mathrm{w} / \mathrm{v})$ triphenyl tetrazolium chloride (TTC) was added to the wells and the incubation of the plates was continued for $30 \mathrm{~min}$ at $35^{\circ} \mathrm{C}$. The presence of red staining was considered as evidence of bacterial growth ${ }^{(21)}$. The absorbance at $450 \mathrm{~nm}$ was measured in a microplate reader (TP Reader Basic, Thermo Plate) to analyze the antibacterial action of the venom. Statistical analysis of the results was performed with a t-test at a significance of $5 \%(\mathrm{p}<0.05)$.

Bacterial strains sensitive to the action of the venom in the microdilution tests were grown on nutrient agar. This was achieved by plating directly onto nutrient agar the content of wells with the following concentrations: twice the MIC, the MIC and half the MIC values. The plates were incubated for $24 \mathrm{~h}$ at $35^{\circ} \mathrm{C}$. The MLC was the lowest concentration of the venom capable of causing the death of $99.9 \%$ of the microbial cells; in other words, the concentration at which no colony growth occurred the agar surface $^{(22)}$.

The alterations in membrane permeability by $C$. $d$. terrificus venom was accessed by the crystal violet assay ${ }^{(23)}$ with modifications. The standard strain of $S$. aureus ATCC 25923 was selected as the indicator microorganism for this experiment. Briefly, the strain was grown in BHI broth and suspended in $1.5 \mathrm{~mL}$ phosphate buffered saline (PBS) ( $\mathrm{pH} 7.4$ ) until a turbidity of 0.5 on the MacFarland scale was achieved. Then, the suspension was centrifuged at $4,500 \times g$ for 5 min at $4{ }^{\circ} \mathrm{C}$, and the sedimented cells were washed twice and resuspended in PBS. The bacterial suspension was further fractionated in $250 \mu \mathrm{L}$ aliquots. These fractions were treated with venom concentrations equivalent to the half of the MIC value (MIC/2), the MIC value, and the MLC value by the addition $250 \mu \mathrm{L}$ of the crude extract and incubated. After an initial incubation for $30 \mathrm{~min}$ at $37{ }^{\circ} \mathrm{C}$, the suspensions were centrifuged for $5 \mathrm{~min}$ at $9,300 \times \mathrm{g}$. The supernatant was discarded, and the pellet was resuspended in $500 \mu \mathrm{L}$ PBS supplemented with $10 \mu \mathrm{g} / \mathrm{mL}$ crystal violet. The samples were incubated for $10 \mathrm{~min}$ at $37^{\circ} \mathrm{C}$ and centrifuged at $13,400 \times \mathrm{g}$ for $15 \mathrm{~min}$. The positive control was bacterial treatment with $0.25 \mathrm{M}$ EDTA and the negative control consisted of untreated bacterial cells suspended in PBS.

Finally, $100 \mu \mathrm{L}$ aliquots of the supernatant from each treatment and the controls were transferred to sterile 96-well microplates. The absorbance at $595 \mathrm{~nm}$ was measured in an automatic microplate reader and the results were statistically analyzed by the t-test at the $5 \%$ significance level. To calculate the percentage of crystal violet uptake by bacterial cells, the formula given below was used. The mean absorbance of the $10 \mu \mathrm{g} / \mathrm{mL}$ violet crystal solution in PBS was considered to be $100 \%$ :

$$
\% \text { Crystal Violet Uptake }=\frac{O D_{595 \mathrm{~nm}} \text { value of the sample }}{O D_{595 \mathrm{~nm}} \text { value of the violet crystal }} \times 100
$$

To determine the protein profile, $12 \%$ polyacrylamide gel electrophoresis (SDS-PAGE) of $C . d$. terrificus venom was performed by on samples at concentrations of $50 \mathrm{mg} / \mathrm{mL}$ and $10 \mathrm{mg} / \mathrm{mL}^{(24)}$. The protein concentration was determined by the Bradford assay using bovine serum albumin (BSA) to make the standard solutions ${ }^{(25)}$. Standard curves of BSA solutions between 0 and $125 \mathrm{mg} / \mathrm{mL}$ were prepared in triplicate and the absorbance at $595 \mathrm{~nm}$ was measured.

The proteolytic activity of the venom was verified in accordance with a previously established 
protocol $^{(26)}$. In a test tube, $2.0 \mathrm{~mL}$ of $1.0 \%(\mathrm{w} / \mathrm{v})$ casein solution in $0.1 \mathrm{M}$ phosphate buffer $(\mathrm{pH} 7.0)$ and $1.0 \mathrm{~mL}$ of $0.1 \mathrm{mg} / \mathrm{mL}$ venom were added. After incubation for $30 \mathrm{~min}$ at $37^{\circ} \mathrm{C}$, the reaction was stopped by the addition of $4.0 \mathrm{~mL}$ of $5 \%$ trichloroacetic acid and incubation was continued for 30 min at room temperature. Finally, the tubes were centrifuged for $5 \mathrm{~min}$ at $10.000 \mathrm{rpm}$ and the absorbance at $280 \mathrm{~nm}$ was measured.

The samples were analyzed in triplicate and the mean of the three results was used to calculate the units of caseinolytic activity through the application of the following formula:

$$
U / m g=\frac{O D_{280 n m} \text { value of the sample }}{\operatorname{Venom}(\mathrm{mg})} \times 100
$$

\section{Results and Discussion}

The crude venom of $C . d$. terrificus exhibited antimicrobial activity against gram-positive and gramnegative bacteria in the microdilution test. The MIC values were determined for $P$. aeruginosa ATCC $27853(62.5 \mu \mathrm{g} / \mathrm{mL})$, S. aureus ATCC $25923(125 \mu \mathrm{g} / \mathrm{mL})$, and M. luteus ATCC $9341(\leq 500 \mu \mathrm{g} / \mathrm{mL})$ (Figure 1). A decrease of more than $50 \%$ was observed in the cellular proliferation of $S$. enterica serovar Typhimurium ATCC 14028 (500 to $62.5 \mu \mathrm{g} / \mathrm{mL})$ and C. glutamicum ATCC 13032 (500 $\mu \mathrm{g} / \mathrm{mL}$ ) (Figure 1). Although inhibition was not detected visually by using the TTC, statistical analysis revealed that the results were significant.

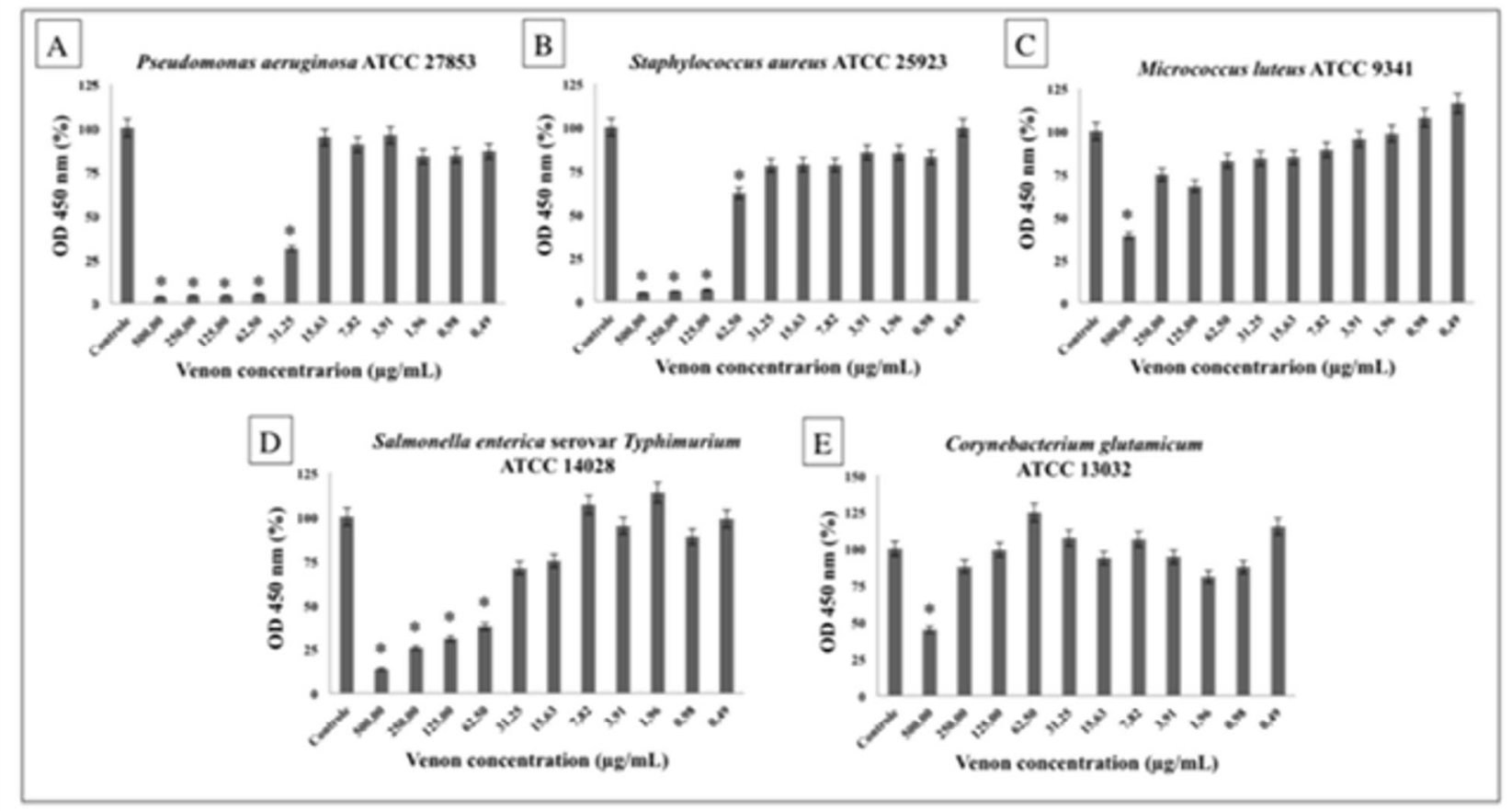

Figure 1 - Broth microdilution test results for P. aeruginosa ATCC 27853 (A), S. aureus ATCC 25923 (B), M. luteus ATCC 9341 (C), S. enterica serovar Typhimurium ATCC 14028 (D), and C. glutamicum ATCC 13032 (E). The plotted data were obtained from the average of the absorbance values $(\lambda=450 \mathrm{~nm})$. The "control" is equivalent to the control of bacterial growth in the absence of venom. ${ }^{*} \mathrm{p}<0.05$ (statistically significant by t-test).

Some authors conceptualize the MIC as the lowest concentration of an antibiotic or chemotherapeutic agent capable of the reduction of microbial growth by at least $50 \%{ }^{(27)}$. In view of this definition, the 
MIC for $S$. enterica serovar Typhimurium ATCC 14028 was determined as $62.5 \mu \mathrm{g} / \mathrm{mL}$ and $\leq 500$ $\mu \mathrm{g} / \mathrm{mL}$ for $C$. glutamicum ATCC 13032. It is valid to stress that TTC is enzymatically reduced by living microorganisms to produce triphenyl formazan, a red stain that is held within granules in cells $^{(21)}$. Thus, the remaining number of viable cells of these two bacterial species mentioned above was sufficiently effective in the reduction of TTC, so that its presence could be visually detected.

Several studies have demonstrated the antibiotic activity of $C$. $d$. terrificus venom against different bacteria $^{(28,29)}$. Other studies have shown that the venom has antiviral activity against dengue fever, yellow fever ${ }^{(30)}$, and human immunodeficiency virus ${ }^{(31)}$, antiprotozoal activity against Leishmania amazonensis $^{(32)}$ and Giardia duodenalis ${ }^{(33)}$, and antifungal activity against Candida spp., Trichosporon spp., and Cryptococcus neoformans ${ }^{(28)}$.

Variations in venom composition, even among snakes from the same species, have already been reported and are probably influenced by factors such as diet and geographic distribution ${ }^{(34,35)}$, which has been demonstrated in some studies evaluating C.d. terrificus $^{(36,48)}$. The effect of the crude venom of $C$. adamanteus from the Crotalus genus was evaluated by using the disc-diffusion method and was also thought inhibit the growth of $S$. aureus, Proteus vulgaris, and Proteus mirabilis, but did no exert activity against $P$. aeruginosa ${ }^{(27)}$, which was different from the results of our study of these bacteria.

MIC was defined by a more sensitive methodology than the disk-diffusion method commonly used to evaluate the potential of antimicrobial agents ${ }^{(37)}$. Natural products are often difficult to diffuse in the culture media used in agar diffusion tests, owing to their water solubility and molecular weight characteristics. Therefore, the broth dilution method is a better option to determine their antibiotic $\operatorname{activity}^{(38)}$.

The antibacterial property of crotalic venom arises from the synergistic association of the constituent antimicrobial peptides and enzymes ${ }^{(39)}$, including phospholipase $\mathrm{A}_{2}\left(\mathrm{PLA}_{2}\right)$, which degrades bacterial membrane phospholipids, and L-amino acid oxidase (LAAO) $(39,40)$. LAAO is commonly associated with the yellowish coloration of snake venoms and affects the oxidative deamination of Lamino acids, a process that generates hydrogen peroxide $\left(\mathrm{H}_{2} \mathrm{O}_{2}\right)$. Several studies have suggested that this protein plays an antimicrobial role mediated by the production of $\mathrm{H}_{2} \mathrm{O}_{2}$, a compound that induces the rupture of membranes in the microorganism, not by direct action on this structure, but by the promotion of oxidative stress and, consequently, induction of death in the microbial cells ${ }^{(40,41)}$. Antimicrobial peptides act on bacterial cells through multiple mechanisms and can interact directly on the membrane, through an intracellular receptor, or stimulate innate immunity ${ }^{(42)}$.

The antibacterial effects were not solely attributable to PLA 2 , as they may depend on the performance of other components from the non-enzymatic fraction of the venom ${ }^{(39)}$. This was corroborated by Yamane et al. ${ }^{(28)}$, who observed a weak inhibition in the growth of E. coli, P. aeruginosa, S. aureus, and $M$. luteus treated with crotamine, a peptide portion of the crotalic venom. The antimicrobial activity of crotamine was attributed to a mechanism involving cell permeability. This toxin is structurally similar to human $\beta$-defensins, which, among other functions, exert an antibiotic effect through their ability to form pores in the bacterial membrane. For the above-mentioned reasons, crotamine has been categorized in the family of antimicrobial peptides (AMPs) ${ }^{(43-46)}$.

The MLC of the venom defined for P. aeruginosa ATCC 27853 and S. aureus ATCC 25923 was immediately higher than MIC, of $125 \mu \mathrm{g} / \mathrm{mL}$ and $250 \mu \mathrm{g} / \mathrm{mL}$, respectively. The MLC determined for 
M. luteus was the same as the MIC (MIC $=\mathrm{MLC}=500 \mu \mathrm{g} / \mathrm{mL})$. For other indicator strains, it was not possible to define MLC accurately. The uptake of crystal violet by $S$. aureus ATCC 25923 was $51.4 \%$ in the absence of venom treatment, but increased to $72.5 \%$ and $78.2 \%$ after treatment with the MIC and MLC of venom, respectively (Figure 2).

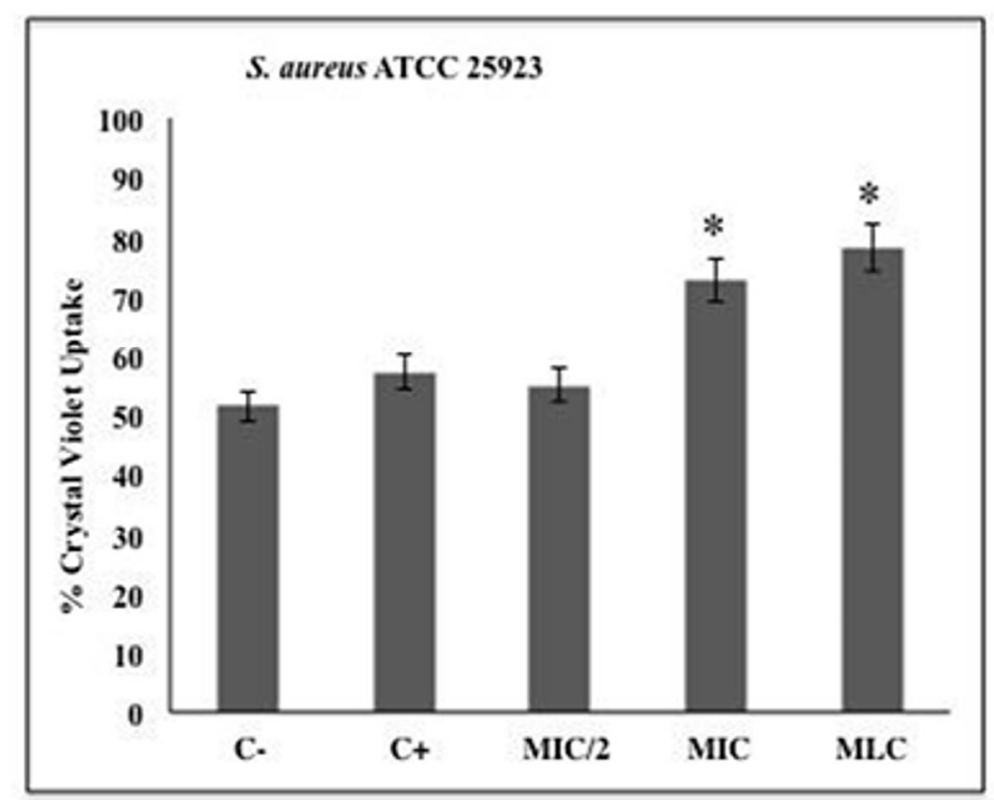

Figure 2 - Crystal violet crystal uptake by $S$. aureus ATCC 25923 treated with 0.25 M EDTA and different concentrations of $C$. d. terrificus venom. C-: negative control (no treatment, only in PBS); C+: positive control (treatment with $0.25 \mathrm{M}$ EDTA); $\mathrm{MIC} / 2$ : venom at $62.5 \mu \mathrm{g} / \mathrm{mL}$; MIC: venom at $125 \mu \mathrm{g} / \mathrm{mL}$; MLC: venom at $250 \mu \mathrm{g} / \mathrm{mL}$. ${ }^{*} \mathrm{p}<0.05$ (statistically significant by t-test).

These results suggested that the constituents of the venom increase the permeability of the bacterial cell membrane, as crystal violet has difficulty penetrating intact membranes, but accumulates in cells with damaged membrane ${ }^{(23)}$. The alteration caused by EDTA (the positive control) is explained by the reduction in the supply of divalent cations, such as calcium $\left(\mathrm{Ca}^{2+}\right)$ and magnesium $\left(\mathrm{Mg}^{2+}\right)$, to the bacterial cell ${ }^{(47)}$. These ions have a fundamental role as macromolecule ligands of the plasma membrane and their restriction confers an osmotic imbalance that ultimately results in increased cellular permeability.

The protein profile exhibited by SDS-PAGE revealed a predominance of proteins with molecular weights below $20 \mathrm{kDa}$, and another considerable protein band in the $100 \mathrm{kDa}$ range (Figure 3 ).

A concordant electrophoretic profile was obtained ${ }^{(48)}$ when analyzing the venom of 92 C. d. terrificus male and female snakes of different ages kept in captivity. Different subspecies of $C$. durissus (C. $d$. terrificus, $C . d$. collilineatus, and $C$. $d$. cascavella) exhibited a comparable pattern of proteins that do not differ greatly, as with their molecular weights ${ }^{(49)}$.

The crude venom had a high protein content $(1.903-2.674 \mathrm{mg} / \mathrm{mL})$; our data were consistent with the reported value of $2 \mathrm{mg} / \mathrm{mL}$ protein ${ }^{(50)}$. Finally, C. $d$. terrificus venom exhibited statistically insignificant proteolytic activity (Figure 4$)(\mathrm{p}=0.205)$. 


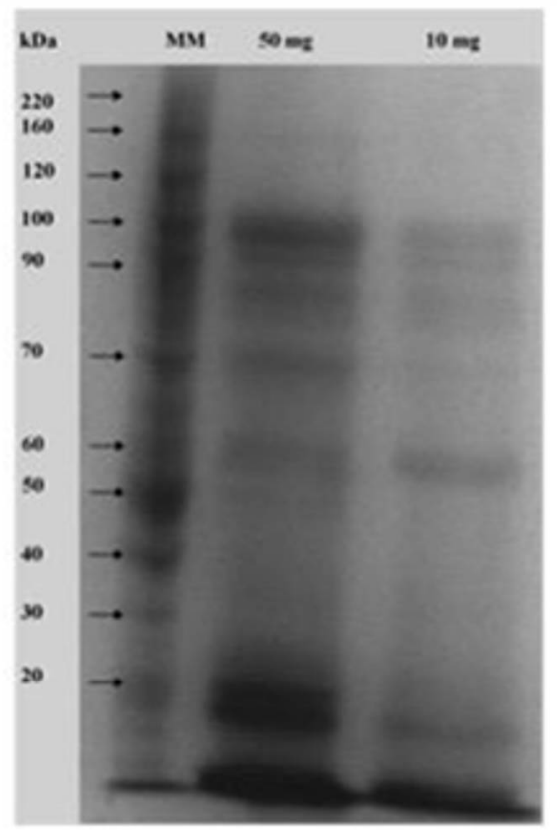

Figure 3 - SDS-PAGE of the $C$. $d$. terrificus crude venom. Molecular Markers (MM) (kDa) (Amersham Biosciences); $50 \mathrm{mg} / \mathrm{mL}$ and $10 \mathrm{mg} / \mathrm{mL}$ concentrations of crude venom of $C$. $d$. terrificus.

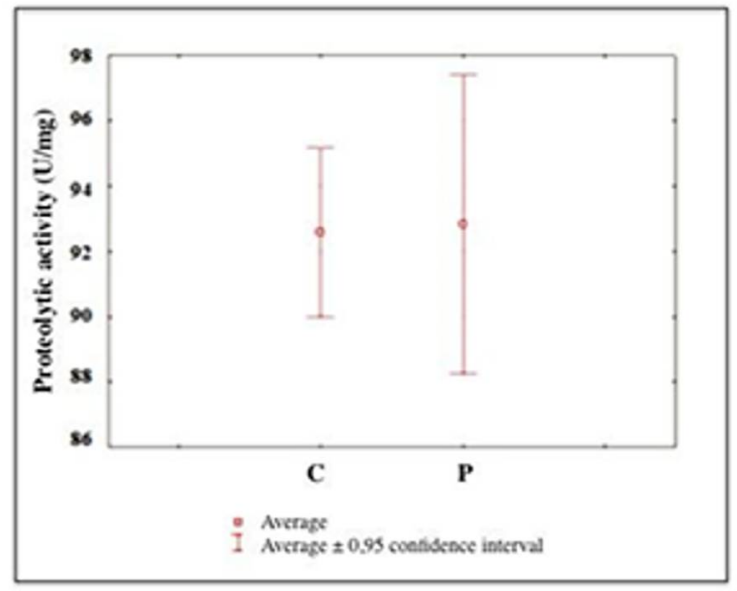

Figure 4 - Proteolytic activity on casein (U/mg). C: control (casein solution without addition of the venom); P: $100 \mu \mathrm{g}$ of $C$. d. terrificus crude venom.

The venom from $C$. durissus subspecies has negligible proteolytic activity ${ }^{(49)}$. In contrast, Bothrops snakes show strong proteolytic action resulting from the action of proteases, hyaluronidases, and phospholipases $^{(51)}$, which cause local lesions such as edema, blisters, and necrosis ${ }^{(52)}$. The proteolytic and cytotoxic actions are closely related ${ }^{(53)}$; therefore, it was inferred that the low proteolytic action of venom also implies decreased cytotoxicity ${ }^{(53)}$.

\section{Conclusions}

The crude venom of $C$. $d$. terrificus exhibited antimicrobial potential against gram-positive and gramnegative bacteria. Moreover, the crystal violet assay demonstrated that the venom increased bacterial cell permeability. The results suggested that isolated venom components may assist in the 
development of new drugs with antibiotic action. However, further investigations must be performed to clarify the fraction responsible for this biological activity of the venom. Other peculiarities of the venom should also be elucidated, such as its toxicity and the characterization of its protein components.

\section{Acknowledgements}

We thank Dr. José Daniel Gonçalves Vieira for providing lab space and material to set up the experimental part of this work.

\section{Conflict of interest}

The authors declare no conflicts of interest.

\section{References}

1.Campbell JA, Lamar WW. The venomous reptiles of the Western Hemisphere. Ithaca: Cornell University Press; 2004.

2. Vanzolini PE, Calleffo MEV. A taxonomic bibliography of the South American snakes of the Crotalus durissus complex (Serpentes, Viperidae). Anais da Academia Brasileira de Ciências. 2002;74(1), 37-83.

3. Wüster W, Ferguson JE, Quijada-Mascareñas JA, Pook CE, Salomão Mda G, Thorpe RS. Tracing an invasion: landbridges, refugia, and the phylogeography of the Neotropical rattlesnake (Serpentes: Viperidae: Crotalus durissus). Molecular Ecology. 2005;14(4):1095-1108.

4. Duarte MR, Menezes FA. Is the population of Crotalus durissus (Serpentes, Viperidae) expanding in Brazil? Journal of Venomous Animals and Toxins including Tropical Diseases. 2013;19(30).

5.Casewell NR, Wagstaff SC, Wüster W, Cook DAN, Bolton FMS, King SI, Pla D, Sanz L, Calvete JJ, Harrison RA. Medically important differences in snake venom composition are dictated by distinct postgenomic mechanisms. PNAS. 2014;111(25):9205-9210.

6. Tasoulis T, Isbister GK. A review and database of snake venom proteomes. Toxins. 2017;9(9):290.

7. Koh DCI, Armugam A, Jeyaseelan K. Snake venom components and their applications in biomedicine. Cellular and Molecular Life Sciences. 2006;63(24):3030-3041.

8. Marchi-Salvador DP, Corrêa LC, Magro AJ, Oliveira CZ, Soares AM, Fontes MR. Insights into the role of oligomeric state on the biological activities of crotoxin: Crystal structure of a tetrameric phospholipase $\mathrm{A}_{2}$ formed by two isoforms of crotoxin B from Crotalus durissus terrificus venom. Proteins. 2008;72:883-891.

9. da Silva Araújo L, Conceição ASMM, de Souza Cunha DM, de Morais GB, de Moraes Silveira JA, Júnior FAFX, Macambira KDS, Araújo SL, Pessoa NO, Evangelista JSAM. Crotalus durissus venom: biological effects and relevant applications. Revista Brasileira de Higiene e Sanidade Animal. 2016;10(1):9-21.

10. Vonk FJ, Jackson K, Doley R, Madaras F, Mirtschin PJ, Vidal N. Snake venom: from fieldwork to the clinic. Bioessays. 2011;33(4):269-279.

11. Hodgson WC, Isbister GK. The application of toxins and venoms to cardiovascular drug discovery. Current Opinion in Pharmacology. 2009;9(2):173-176. 
12. Sajevic T, Leonardi A, Križaj I. Haemostatically active proteins in snake venoms. Toxicon. 2011;57(5):627-645.

13. Fernandes-Pedrosa MF, Félix-Silva J, Menezes YA. Toxins from venomous animals: gene cloning, protein expression and biotechnological applications. In: An Integrated View of the Molecular Recognition and Toxinology-From Analytical Procedures to Biomedical Applications [Internet]. InTech; 2013. Available from: https://www.intechopen.com/books/an-integrated-view-of-the-molecular-recognition-and-toxinology-fromanalytical-procedures-to-biomedical-applications/toxins-from-venomous-animals-gene-cloning-proteinexpression-and-biotechnological-applications

14. Barros GA, Pereira AV, Barros LC, Lourenço Jr A, Calvi SA, Santos LD, et al. In vitro activity of phospholipase A2 and of peptides from Crotalus durissus terrificus venom against amastigote and promastigote forms of Leishmania (L.) infantum chagasi. Journal of Venomous Animals and Toxins including Tropical Diseases. 2015;21(1):48.

15.Bandeira I, Bandeira-Lima D, Mello C, Pereira T, De Menezes R, Sampaio T, Martins A. Antichagasic effect of crotalicidin, a cathelicidin-like vipericidin, found in Crotalus durissus terrificus rattlesnake's venom gland. Parasitology. 2018;145(8):1059-1064.

16. de Oliveira Junior NG, Silva-Cardoso MH, Franco OL. Snake venoms: attractive antimicrobial proteinaceous compounds for therapeutic purposes. Cellular and Molecular Life Sciences. 2013;70(24):46454658 .

17. Almeida JR, Lancellotti M, Soares AM, Calderon LA, Ramírez D, González W, Marangoni S, Da Silva SL. CoaTx-II, a new dimeric Lys49 phospholipase A2 from Crotalus oreganus abyssus snake venom with bactericidal potential: insights into its structure and biological roles. Toxicon. 2016; 120:147-58.

18. Costa Torres AF, Dantas RT, Toyama MH, Diz Filho E, Zara FJ, Rodrigues de Queiroz MG, Pinto Nogueira NA, Rosa de Oliveira M, de Oliveira Toyama D, Monteiro HS, Martins AM. Antibacterial and antiparasitic effects of Bothrops marajoensis venom and its fractions: phospholipase A2 and 1-amino acid oxidase. Toxicon. 2010;55(4):795-804.

19. Ribeiro CB, Dos Santos JC, Silva JM, de Godoi PH, Magalhães MR, Spadafora-Ferreira M, Fonseca SG, Pfrimer IA. Crotalus durissus collilineatus venom induces TNF- $\alpha$ and IL-10 production in human peripheral blood mononuclear cells. ISRN Inflammation. 2014; 2014:563628.

20.CLSI, Clinical and Laboratory Standards Institute. Methods for Dilution Antimicrobial Susceptibility Tests for Bacteria That Grow Aerobically; Approved Standard - Tenth Edition. CLSI document M07-A10. Wayne, PA: Clinical and Laboratory Standards Institute; 2015.

21. Ramos TZ, Pizzolitto EL, Pizzolitto AC. Uso do teste com cloridrato de trifenil tetrazólio (CTT) para detecção de bacteriúria sintomática e assintomática. Revista Brasileira de Análises Clínicas. 2006;38(3):197199.

22. Sales GWP, Batista AH de M, Rocha LQ, Nogueira NAP. Efeito antimicrobiano e modulador do óleo essencial extraído da casca de frutos da Hymenaea courbaril L. Revista de Ciências Farmacêuticas Báscia e Aplicada [Internet]. 2015;35(4). Available from: http://servbib.fcfar.unesp.br/seer/index.php/Cien_Farm/article/viewArticle/3463

23. Devi KP, Nisha SA, Sakthivel R, Pandian SK. Eugenol (an essential oil of clove) acts as an antibacterial agent against Salmonella typhi by disrupting the cellular membrane. Journal of Ethnopharmacology. 2010;130(1):107-115.

24. Laemmli UK. Cleavage of structural proteins during the assembly of the head of bacteriophage T4. Nature. 1970;227:680-685. 
25. Bradford MM. A rapid and sensitive method for the quantitation of microgram quantities of protein utilizing the principle of protein-dye binding. Analytical Biochemistry. 1976;72(1-2):248-254.

26. Lomonte B, Gutiérrez JM. La actividad proteolítica de los venenos de serpientes de Costa Rica sobre la caseína. 1983; Available from: http://repositorio.ucr.ac.cr/handle/10669/9245

27. Perumal Samy R, Gopalakrishnakone P, Thwin MM, Chow TK, Bow H, Yap EH, Thong TW. Antibacterial activity of snake, scorpion and bee venoms: a comparison with purified venom phospholipase A2 enzymes. Journal of Applied Microbiology. 2007;102(3):650-659.

28. Yamane ES, Bizerra FC, Oliveira EB, Moreira JT, Rajabi M, Nunes GL, de Souza AO, da Silva ID, Yamane T, Karpel RL, Silva PI Jr, Hayashi MA. Unraveling the antifungal activity of a South American rattlesnake toxin crotamine. Biochimie. 2013;95(2):231-240.

29. Perumal Samy R, Manikandan J, Sethi G, L Franco O, Okonkwo JC, Stiles BG, Chow VTK, Gopalakrishnakone P, Al Qahtani M. Snake venom proteins: development into antimicrobial and wound healing agents. Mini-Reviews in Organic Chemistry. 2014;11(1):4-14.

30. Muller VD, Russo RR, Cintra AC, Sartim MA, Alves-Paiva R de M, Figueiredo LT, Sampaio SV, Aquino VH. Crotoxin and phospholipases A2 from Crotalus durissus terrificus showed antiviral activity against dengue and yellow fever viruses. Toxicon. 2012;59(4):507-515.

31. Meenakshisundaram R1, Sweni S, Thirumalaikolundusubramanian P. Hypothesis of snake and insect venoms against human immunodeficiency virus: a review. AIDS Research and Therapy [Internet]. 2009;6(25). Available from: https://www.cabdirect.org/cabdirect/abstract/20103011336

32. Macedo SR, de Barros NB, Ferreira AS, Moreira-Dill LS, Calderon LA, Soares AM, Nicolete R. Biodegradable microparticles containing crotamine isolated from Crotalus durissus terrificus display antileishmanial activity in vitro. Pharmacology. 2015;95(1-2):78-86.

33. Shinohara L, de Freitas SF, da Silva RJ, Guimarães S. In vitro effects of Crotalus durissus terrificus and Bothrops jararaca venoms on Giardia duodenalis trophozoites. Parasitology Research. 2006;98(4):339-344.

34.Barlow A, Pook CE, Harrison FA, Wuster W. Coevolution of diet and prey-specific venom activity supports the role of selection in snake venom evolution. Proccedings of the Royal Society B. (2009);276:2443-2449.

35.Vonk FJ, Casewell NR, Henkel CV, Heimberg AM, Jansen HJ, McCleary RJ, Kerkkamp HM, Vos RA, Guerreiro I, Calvete JJ, Wüster W, Woods AE, Logan JM, Harrison RA, Castoe TA, de Koning AP, Pollock DD, Yandell M, Calderon D, Renjifo C, Currier RB, Salgado D, Pla D, Sanz L, Hyder AS, Ribeiro JM, Arntzen JW, van den Thillart GE, Boetzer M, Pirovano W, Dirks RP, Spaink HP, Duboule D, McGlinn E, Kini RM, Richardson MK. The king cobra genome reveals dynamic gene evolution and adaptation in the snake venom system. Proceedings of the National Academy of Sciences. 2013;110(51):20651-20656.

36.Magro AJ, Silva RJ, Ramos PRR, Cherubini AL, Hatayde MR. Intraspecific variation in the venom electrophoretic profile of recently captured Crotalus durissus terrificus (Laurenti, 1768) snakes. Journal of Venomous Animals and Toxins. 2001;7(2):276-301.

37. Balouiri M, Sadiki M, Ibnsouda SK. Methods for in vitro evaluating antimicrobial activity: a review. Journal of Pharmaceutical Analyses. 2016;6(2):71-79.

38. Alves EG, Vinholis AHC, Casemiro LA, Furtado N, Silva MLA, Cunha WR, Martins CHG. Estudo comparativo de técnicas de screening para avaliação da atividade antibacteriana de extratos brutos de espécies vegetais e de substâncias puras. Química Nova. 2008;31(5):1224-1229.

39. Santamaría C, Larios S, Angulo Y, Pizarro-Cerda J, Gorvel J-P, Moreno E, Lomonte B. Antimicrobial activity of myotoxic phospholipases A2 from crotalid snake venoms and synthetic peptide variants derived from their C-terminal region. Toxicon. 2005;45(7):807-815. 
40. Guo C, Liu S, Yao Y, Zhang Q, Sun M-Z. Past decade study of snake venom L-amino acid oxidase. Toxicon. 2012;60(3):302-311.

41. Toyama MH, Toyama Dde O, Passero LF, Laurenti MD, Corbett CE, Tomokane TY, Fonseca FV, Antunes E, Joazeiro PP, Beriam LO, Martins MA, Monteiro HS, Fonteles MC. Isolation of a new L-amino acid oxidase from Crotalus durissus cascavella venom. Toxicon. 2006;47(1):47-57.

42. Epand RM, Epand RF. Bacterial membrane lipids in the action of antimicrobial agents. Journal of Peptide Science. 2011;17(5):298-305.

43. Nicastro G, Franzoni L, de Chiara C, Mancin AC, Giglio JR, Spisni A. Solution structure of crotamine, a $\mathrm{Na}^{+}$channel affecting toxin from Crotalus durissus terrificus venom. The FEBS Journal. 2003;270(9):19691979.

44. Oguiura N, Boni-Mitake M, Affonso R, Zhang G. In vitro antibacterial and hemolytic activities of crotamine, a small basic myotoxin from rattlesnake Crotalus durissus. Journal of Antibiotics (Tokyo). 2011;64(4):327.

45. Coronado MA, Gabdulkhakov A, Georgieva D, Sankaran B, Murakami MT, Arni RK, Betzel C. Structure of the polypeptide crotamine from the Brazilian rattlesnake Crotalus durissus terrificus. Acta Crystallographica Section D, Biological Crystallography. 2013;69(10):1958-1964.

46. Sieber M, Bosch B, Hanke W, de Lima VMF. Membrane-modifying properties of crotamine, a small peptide-toxin from Crotalus durissus terifficus venom. Biochimica et Biophysica Acta (BBA) - General Subjects. 2014;1840(3):945-950.

47. Bordignon-Junior SE, Miyaoka MF, da Luz Costa J, Benavente CAT, Couto GH, Soccol CR. Inhibiting Gram-negative bacteria growth in microdilution by Nisin and EDTA treatment. Journal of Biotechnology and Biodiversity [Internet]. 2012;3(4). Available from: https://sistemas.uft.edu.br/periodicos/index.php/JBB/article/view/412

48. Lourenço A Jr, Zorzella Creste CF, de Barros LC, Delazari dos Santos L, Pimenta DC, Barraviera B, Ferreira RS Jr.. Individual venom profiling of Crotalus durissus terrificus specimens from a geographically limited region: crotamine assessment and captivity evaluation on the biological activities. Toxicon. 2013;69:75-81.

49. Santoro ML1, Sousa-e-Silva MC, Gonçalves LR, Almeida-Santos SM, Cardoso DF, Laporta-Ferreira IL, Saiki M, Peres CA, Sano-Martins IS. Comparison of the biological activities in venoms from three subspecies of the South American rattlesnake (Crotalus durissus terrificus, C. durissus cascavella and C. durissus collilineatus). Comparative Biochemistry and Physiology Part C: Pharmacology, Toxicology and Endocrinology. 1999;122(1):61-73.

50. Clissa PB, do Nascimento N, Rogero JR. Toxicity and immunogenicity of Crotalus durissus terrificus venom treated with different doses of gamma rays. Toxicon. 1999;37(8):1131-1141.

51. Castro I de. Estudo da toxicidade das peçonhas crotálicas e botrópicas, no acidente ofídico, com ênfase a toxicidade renal. O Mundo Saúde. 2006;30:644-653.

52. BRASIL, Ministério da Saúde. Manual de diagnóstico e tratamento de acidentes por animais peçonhentos. 2 edição. 2001. 09-36 p.

53. Tokarnia CH, Peixoto PV. A importância dos acidentes ofídicos como causa de mortes em bovinos no Brasil. Pesquisa Veterinária Brasileira. 2014;26(2):55-68. 